\title{
Enhancing the Societal Impact of the Olympics: An Interorganizational Partnership Approach
}

\author{
James W. Fairfield-Sonn \\ University of Hartford
}

To enhance their organization's impact on society, nonprofit leaders need to consider using a combination of different ways to effectively generate more support for both their organization's operations and mission. The aim of this paper is to contribute to that search for potentially viable sources of additional nonprofit organizational support in two ways. First, it provides an in-depth case study on how the leaders of the Olympic Movement have been able to enhance their organization's societal impact by successfully building an interorganizational partnership with a number of global for-profit firms. Second, how the Olympics' experience might be helpful to other nonprofits in evaluating the potential value of using a similar or modified version of this approach as part of their own organizational development efforts. Management policy and practice implications are discussed.

Keywords: societal impact, sustainability-focused strategies, olympics, interorganizational relations, nonprofit organizations, double bottom-line

\section{INTRODUCTION}

To increase their impact on society (DeRycke \& DeBosscher, 2019), a significant social entrepreneurship challenge for many nonprofits is to find ways to generate more support for both their operations and mission (Kickul \& Lyons, 2020). As a result, nonprofits have been developing a wide variety of pragmatic to virtuous strategies (McDonald et al, 2015) to pursue these critical, double bottom-line, goals for some time. Given the increasing competition for limited resources, however, there is a continuing need to identify more sustainability-focused strategies that nonprofits can also consider using in their pursuit of these goals (Roche, 2017).

The purpose of this paper, therefore, is to add to the literature on sustainability-focused strategies that have been successfully used by a nonprofit(s), to simultaneously achieve both of these goals (David et al, 2019). Specifically, attention here is directed at exploring how a structured, interorganizational (Franke, 2017) sponsorship program can provide another way for a nonprofit to obtain more support for its operations and mission. In this instance, the focus is on how a program created by a global, nonprofit sports organization has proven to be effective in creating a long-term, shared value (Porter \& Kramer, 2011) partnership between the nonprofit and many global, for-profit firms.

More precisely, this paper examines how the International Olympic Committee (IOC) successfully launched The Olympic Partner (TOP) Sponsors Program in 1985 as a formal, structured program (David et al, 2019) with the intent to use it to add another dimension to the organization's existing organizational support model. To make this program work, however, the IOC also needed to commit the organization to 
begin (re)defining a set of on-going relationships as well as creating the possibility for a new set of relationships with some of the largest, global, private-sector companies in the world. This step was necessary because to become involved in this program moving forward, it would mean that potential partners would need to be willing to make a substantial, multi-year commitment to join a small group of fellow sponsors in providing significant support for both the operations and mission of the Olympics around the world.

Today, we know that this once experimental TOP Sponsors program has gone on to successfully provide increasing levels of support for both the financial and mission goals of the Olympics for over three decades. Accordingly, it qualifies as a sustainability-focused strategy that deserves more attention and wider consideration. In examining this program, two related management policy and practice questions about this sustainability-focused strategy are examined here in some detail. First, how did this global nonprofit enhance its societal impact (DeRycke \& DeBosscher, 2019), by successfully building an interorganizational, major sponsor program with many global private companies over the last several decades? Second, how might that organization's experience be helpful to other nonprofits in evaluating the potential usefulness of using a similar or modified version of this approach as part of their own organizational development efforts?

In addressing these two questions, attention is first directed at how the organizers of the Modern-era Olympics designed and launched The Olympic Partners (TOP) Sponsors program in 1985. Then, how that effort has since led to some new relationships between the organizers of the Olympics and an evolving group of global, corporate sponsors who have been willing to invest significantly in both the staging of the Games and communicating the values-driven mission of the Olympic Movement (Olympic Marketing Fact File, 2020). This is followed by a discussion of some key issues that other nonprofits should consider if they decide to create their own interorganizational program.

\section{Potential Societal Impact of Elite Sports on Society}

How can elite sports potentially impact society? There is a growing body of empirical evidence indicating that elite, global, mega-sporting events like the Olympic Games and the FIFA World Cup (Müller \& Gaffney, 2018) can and do have positive and negative impacts on society in a variety of ways. For example, based on a recent literature review of empirical articles on this topic, DeRychke and DeBosscher (2019) identified 10 categorical areas of research (e.g., social equality and inclusion in sporting events; prestige and image associated with winning medals) in which elite sporting events have been shown to have had either positive and/or negative impacts on society. Thus, a body of evidence has been growing to demonstrate some of the many ways in which a sports-oriented nonprofit can indeed impact society. In this instance, the research focusses specifically on the impact category identified by DeRychke and DeBosscher (2019) as "Sponsors and commercial activity" where previous empirical research efforts have shown positive (e.g., economic boost, innovation) and negative (e.g., association with scandals; financial hangover) societal impacts being linked to these elite sporting events.

\section{Sustainability-Focused Strategies}

How are sustainability-focused strategies defined in this paper? Here, a sustainability-focused strategy includes any approach that enables a nonprofit to more successfully balance its pursuit of the so-called "double bottom-line" goals, namely, money and social mission. To determine whether or not a particular approach can be classified as sustainability-focused, a four-cell typology developed by McDonald et al (2015) is used as the evaluation framework for making that assessment in this paper. Specifically, in reviewing where different nonprofits are in their journey to fiscal and social sustainability McDonald et al, (2015) classified them as being either: in "double jeopardy" (low on both dimensions); "so what" (high fiscal but low social sustainability); "shoe string" (low fiscal but high social sustainability); or exemplary (high on both dimensions). Then, based on the cell the nonprofit was currently in, the authors provided several possible approaches that individually or in combination with other efforts might serve the organization well as it attempts to move into a more sustainable space. For example, nonprofits in the most precarious double jeopardy cell might want to consider ways to increase revenues while decreasing costs 
as well as redefining their mission and creating an educational campaign to increase awareness of the need for their services. In contrast, for nonprofits like the Olympics that fall into the exemplary cell, a more appropriate strategy could be to "proactively innovate to maintain competitive position" (McDonald et. al, 2015, p.976).

\section{The Modern-Era Olympic Games as a Mega-Sporting Event}

What does is mean for the Olympics to have become a global, mega-sporting event? The idea for organizing the Modern-era Olympic Games was first formally presented by Baron Pierre de Coubertin, the Secretary General of the Union des Société's Françoise de Sports Athletiques (USFSA), in 1894 at the Inaugural Olympic Congress held at the Sorbonne University in Paris. That proposal was unanimously accepted on June 23, 1894 (Olympic Congress-Paris-1894). Along with support for that proposal, the 78 Delegates at the Congress also decided to create the IOC to become the supreme organizing body of the first Summer Olympic Games that were held in Athens in 1896 (Olympic Congress-Paris-1894).

Since their humble beginning in 1894, the Modern-era Olympic Games have increased in size and stature to the point that they are now considered to be one of the few truly global, mega-sporting events in the world. Moreover, the Games now include not only the Summer Olympic Games but also the Winter Olympic Games. The first Winter Olympic Games being held in Chamonix, France in 1924.

To put this growth into perspective, it can be helpful to have a sense for how the Olympics compare against other major sporting events today on different measurement systems. For example, using the Gratton \& Taylor (2000) four-level, purely economic importance typology rating system, ranging from a level A - high to a level D - low, the Olympics are consistently at the A level for both economic activity and media interest (Gratton et al, 2000). Alternatively, using the multi-dimensional Müller (2015) model that considers: number of visitors; extent of media reach; associated costs; and impact on the built environment and population, the Olympics are once again rated as being among the largest global, megasporting events in the world.

\section{THEORETICAL PERSPECTIVE}

To examine the development of the structured, interorganizational TOP Sponsors program from its inception in 1985 to its most recent funding cycle, which concludes with the 2020 Tokyo Olympic Games, a sociological, neo-institutional theory perspective (Meyer \& Rowan, 1977; Zucker, 1977; DiMaggio \& Powell, 1983; Tolbert \& Zucker, 1983; David et al., 2019) was used in this paper. This prominent, contempory perspective on organizational studies (Dacin et al., 2002; Greenwood et al., 2008; Greenwood et al., 2017) was selected for several reasons. First, this theoretical perspective's emphasis, in general, is on understanding how cultural interactions and expectations can help to explain why institutions change over time (David et al., 2019). Second, this perspective would also provide an appropriate lens to better understand why the leaders of the Olympic Movement decided to create this interorganizational structure (Tolbert \& Zucker, 1983; Zorn, 2004) to refine the relationship between themselves and a relatively small group of dedicated sponsors for financial and symbolic reasons (DiMaggio, 1988; Dacin et al., 2002). Third, given that this program is based on an international, interorganizational partnership, it is likewise appropriate to use it in this analysis. This is because over the last two decades this theoretical perspective has emerged to become one of the five most used approaches to examining and explaining the ways in which international relations and dynamics change over time (Franke, 2017).

\section{METHODS}

This study was designed to examine three aspects of the creation and implementation of the on-going TOP Sponsors sustainability-focused strategy that could have theoretical and/or practical implications for nonprofit policy development and practice. First, from a sociological, neo-institutional theoretical perspective (David et al., 2019), to what degree has the composition of the firms and the structure of the TOP Sponsors program changed (Roland, 2004) since its inception in 1985 to 2020 ? Second, from a shared 
value (Porter \& Kramer, 2011) perspective, in what ways has the participation (Austin, 2000) by TOP Sponsors in this social alliance (Berger et al, 2004) between a nonprofit and several private firms enhanced the societal impact of the Olympics? Third, based on the findings to the two above questions, are there observations about how the IOC has managed this type of program that might be valuable to other nonprofit firms in their organizational development efforts (Berry et al, 2021)?

\section{Case Selection}

The Olympic TOP Sponsors program was viewed as an appropriate choice for an examination of the above issues for several reasons. First, since 1985 the TOP Sponsors program has moved through nine, full funding cycles, so it was possible to move beyond a cross-sectional to a longitudinal analysis of changes in the Sponsors program network from its inception. Second, the continuing growth in the support provided to the Olympic Movement, by an intentionally small number of global private-sector firms involved in the TOP Sponsors program, makes it a potentially good "best practice" example for the effectiveness of this type of structured program. Third, the increasing general interest in the Olympic Games around the world has made its operations and mission more visible and thus hopefully easier for readers to understand as a case study example.

\section{Sources of Data}

There were several rich sources of publicly available primary data that proved invaluable in the conduct of this examination. First, the Olympic Studies Centre TOP Marketing Program: Historic Overview 19.06.2017 document (The Olympic Studies Centre, 2017) provided an official list of all the TOP Sponsors from 1985 - 2020. Second, the Olympic Marketing Fact File - 2020 Edition (Olympic Marketing Fact File, 2020) provided recent information about the variety of and changes in the major sources of support for the Olympic operations over the last several years. Third, the IOC's design of the TOP Sponsors agreement was clearly spelled out in the guide to the Olympic Partner Programme (Olympic Partner Programme, 2021). Fourth, the Olympic Charter (Olympic Charter, 2020) was vital to understanding the mission, current organizational structure, and major policies of the Olympic Movement. Finally, Google searches yielded information about many of the detailed questions that needed to be addressed in the study such as the current locations of the global headquarters of the private-sector TOP Sponsors.

\section{Data Analysis}

The initial data analysis effort was focused on learning more about possible changes in the composition and/or structure of the TOP Sponsors membership network during the most recent nine Olympic, four-year funding cycles, from the inception of the program in 1985 to the end of its most recent cycle in 2020. To succinctly capture any changes on these two dimensions over time, tables were created for each of the nine funding cycles that paired the names of the cycle sponsors with two concepts that have proven to be valuable in interorganizational social network analysis (Carroll \& Sapinski, 2011). Specifically, one table provided information on any potential "Spatiality" effects. In other words, did the location of the Sponsors' global headquarters suggest a pattern for why some companies may have decided to become partners in this program? Then, a second set of tables were prepared to capture any potential "Temporality" effects based on what companies joined and what companies departed from membership in the network in each of the nine funding cycles.

Next, given the longitudinal nature of this examination, to complement and extend the initial data analysis another table was created to capture the "Length of Commitment" by TOP Sponsors over the course of the nine funding cycles. This was done specifically to see if there was a pattern within the network (Marin \& Wellman, 2011) in how many cycles each company was a TOP Sponsor, and whether they were continuing as a sponsor or if they had stopped serving as a sponsor? Then, a final table was created to access the relative amount of growth in revenues generated by the TOP Sponsors program compared to the growth in four other major sources of revenue during three illustrative Olympiad periods. 


\section{FINDINGS}

\section{Composition and Structure of the TOP Sponsors Program}

In examining the composition and structure of the social alliance TOP Sponsor program membership from its beginning in 1985 to its current membership today several patterns were observed. First, when the IOC officially began the program, the intention was to include around 12 organizations in this elite sponsor category. In reviewing the actual membership for the first funding cycle (see TABLE 1 "TOP FUNDING CYCLE 1: TOP SPONSORS 1985-1988" below) it was found that the membership consisted of only 9 companies. Over time, however, while the membership size has remained relatively small, it has grown to include 14 organizations in 2020 (see TABLE 2 "TOP FUNDING CYCLE 9: TOP SPONSORS 20172020" below).

Second, in terms of discovering any potential "Spatiality" effects, it is notable that while the sponsors are providing support to the Olympic Movement throughout the world, in the first funding cycle, six of the nine companies had headquarters in the United States, two more were headquartered in Japan, and one firm had its global headquarters in the Netherlands (see TABLE 1 " TOP FUNDING CYCLE 1: TOP SPONSORS 1985-1988" below). In contrast, by the ninth funding cycle, seven of the 14 firms were headquartered in the United States, with three in Japan, and one company had its headquarters in each of the following countries: China, France, South Korea, and Switzerland (see TABLE 2 "TOP FUNDING CYCLE 9: TOP SPONSORS 2017-2020" below).

As for "Temporality" effects, TABLE 2 (see TABLE 2 "TOP FUNDING CYCLE 9: TOP SPONSORS 2017-2020" below). also shows that five (highlighted in bold in the table) of the 14 companies in the ninth funding cycle were new to the TOP Sponsor program in that funding cycle. In addition, that with only one exception, McDonald's (shown in bold and italics in the table), all the 10 firms in the eigth funding cycle had continued their membership into the ninth cycle. Also, of note, in reviewing all the cycle transitions, it was evident that one or more member additions and/or departures occurred between every one of the funding cycles.

TABLE 1

TOP FUNDING CYCLE 1: TOP SPONSORS 1985-1988 [SEOUL (SUMMER) AND CALGARY (WINTER) - 9 SPONSORS]

\begin{tabular}{|c|c|}
\hline Company & $\begin{array}{l}\text { Headquarters } \\
\text { (Country: City) }\end{array}$ \\
\hline Coca-Cola & USA: Atlanta, GA \\
\hline Brother & Japan: Nagoya \\
\hline Federal Express & USA: Memphis, TN \\
\hline Kodak & USA: Rochester, NY \\
\hline$\overline{\text { Matsushita }}$ & Japan: Osaka \\
\hline Philips & Netherlands: Amsterdam \\
\hline Time/Sports Illustrated & USA: New York \\
\hline$\underline{\text { Visa }}$ & USA: San Francisco \\
\hline $3 \mathrm{M}$ & USA: St. Paul, MN \\
\hline
\end{tabular}


TABLE 2

TOP FUNDING CYCLE 9: TOP SPONSORS 2017-2020

[TOKYO (SUMMER) AND PYEONGCHANG (WINTER) - 14 SPONSORS]

\begin{tabular}{|c|c|}
\hline Company Name & $\begin{array}{l}\text { Headquarters } \\
\text { (Country: City) }\end{array}$ \\
\hline Continuing Sponsors & Continuing Sponsors \\
\hline Atos & France: Bezons \\
\hline Coca-Cola & USA: Atlanta, GA \\
\hline Dow & USA: Midland, MI \\
\hline General Electric & USA: Boston, MA \\
\hline Omega & Switzerland: Biel/Bienne \\
\hline Panasonic (formerly Matsushita) & Japan: Osaka \\
\hline Proctor and Gamble & USA: Cincinnati, $\mathrm{OH}$ \\
\hline Samsung & South Korea, Seoul \\
\hline Visa & USA: Foster City, CA \\
\hline New Sponsors for Cycle 9 & New Sponsors for Cycle 9 \\
\hline Alibaba Group & China: Hangzhou \\
\hline Airbnb* & USA: San Francisco, CA \\
\hline Bridgestone & Japan: Tokyo \\
\hline Intel & USA: Santa Clara, CA \\
\hline Toyota & Japan: Toyota City \\
\hline Departed Sponsor from Cycle 8 & Departed Sponsor from Cycle 8 \\
\hline McDonald's & USA: Oak Brook, IL \\
\hline
\end{tabular}

*Airbnb became a TOP Sponsor in 1999, so it was not listed in the 2017 TOP Marketing Program report.

Next, a table on the length of commitment by TOP Sponsors to the Olympic program table was prepared (see TABLE 3 "TOP SPONSORS LENGTH OF COMMITMENT TO THE OLYMPIC PROGRAM" below) to see if there were any patterns in the amount of time that TOP Sponsors typically remain involved in this program. What surfaced was that there was a considerable variation on this dimension by current and former members in the program. For example, on the high end of the commitment scale there were three companies (i.e., Coca-Cola, Panasonic (formerly known as Matsushita), and Visa) that have been involved in all nine funding cycles. On the other hand, on the low end of commitment scale there were five firms (i.e., Mars, Ricoh, Lenovo, Johnson \& Johnson, and Acer) that only participated in the program for one funding cycle and then, to date, have not (re)committed to the program. 
TABLE 3

TOP SPONSORS LENGTH OF COMMITMENT TO THE OLYMPIC PROGRAM

\begin{tabular}{|c|c|l|}
\hline $\begin{array}{l}\text { Number of Funding Cycles for } \\
\text { Potential Commitment }\end{array}$ & $\begin{array}{l}\text { Number of Companies in Cycles } \\
\text { of Commitment Category }\end{array}$ & $\begin{array}{l}\text { Participant Status of Companies } \\
\text { in Cycle of Commitment } \\
\text { Category }\end{array}$ \\
\hline 9 & 3 & 3 Continuing \\
\hline 8 & None & N/A \\
\hline 7 & None & N/A \\
\hline 6 & 2 & $\begin{array}{l}\text { 1 Continuing } \\
\text { 1 Departed }\end{array}$ \\
\hline 5 & 4 & $\begin{array}{l}\text { 2 Continuing } \\
\text { 2 Departed } \\
\text { 1 Continuing } \\
\text { 1 Departed }\end{array}$ \\
\hline 4 & 2 & $\begin{array}{l}\text { 2 Continuing } \\
\text { 1 Departed } \\
\text { 7 Departed }\end{array}$ \\
\hline 3 & 3 & $\begin{array}{l}\text { 5 First Time Commitment } \\
5 \text { Departed }\end{array}$ \\
\hline 2 & 7 & \\
\hline 1 & 10 & \\
\hline
\end{tabular}

\section{Design of the IOC'S TOP Sponsors Program}

Given that the TOP Sponsors program has been successfully operating for over three decades, it provides a rich example of how it is possible for a nonprofit to build a mutually beneficial, shared value (Porter \& Kramer, 2011) partnership with a select group of for-profit, private organizations as part of an overall social entrepreneurship growth strategy. That success, in turn, raises the question of what was it about the design of the program that may have contributed to its long-term success? While a definitive answer is beyond the scope of this paper, to enhance the longevity potential of this partnership, three features stand out as likely major contributors. First, in line with Austin's (2000) funding framework, while a substantial contribution was required of potential sponsors, it was not intended to be about making a philanthropic gift, rather it was designed to be a transactional arrangement that could grow into an integrated effort. Second, the contribution was not envisioned to be used for short-term needs, but rather throughout a full, four-year cycle of Olympic activities. Third, along with the purely financial contribution, Sponsors also needed to enter into the agreement with the intent of finding ways to also support the broad mission of the Olympic Movement.

\section{Enhancing the Societal Impact of the Olympics}

Thomas Bach, the current Chair of the IOC has stated that Sponsors are vital to hosting the games and communicating the Olympic values. How exactly does the TOP Sponsor program enhance the IOC's ability to stage the Games and share the mission of the Olympic Movement?

In terms of helping to host the games, currently, each TOP Sponsor provides around $\$ 100$ million to help the IOC with every operational aspect of running the Olympic Games during a four-year funding cycle. In doing so, they have become an ever more important part of the overall major organizational support mix (see TABLE 4 - "REVENUES FROM 5 MAJOR SOURCES DURING 3 OLYMPIADS" below) that also includes revenues from IOC managed broadcasting rights, Host Country domestic sponsorships, ticketing, and licensing (e.g., numismatic, and philatelic programs) (Olympic Marketing Fact File, 2020). 
TABLE 4

REVENUES FROM 5 MAJOR SOURCES DURING 3 OLYMPIADS

\begin{tabular}{|l|c|c|c|}
\hline \multicolumn{1}{|c|}{ Revenue Sources } & $\begin{array}{c}\text { 1993-1996 } \\
\text { Olympiad }\end{array}$ & $\begin{array}{l}\text { 2001-2004 } \\
\text { Olympiad }\end{array}$ & $\begin{array}{c}\text { 2013-2016 } \\
\text { Olympiad }\end{array}$ \\
\hline IOC - Broadcasting & 1,251 & 2,232 & 4,157 \\
\hline $\begin{array}{l}\text { IOC - } \\
\text { TOP Sponsors }\end{array}$ & 279 & 663 & 2,003 \\
\hline $\begin{array}{l}\text { Host Country - } \\
\text { Sponsorships }\end{array}$ & 534 & 796 & 527 \\
\hline $\begin{array}{l}\text { Host Country - } \\
\text { Ticketing }\end{array}$ & 451 & 411 & 74 \\
\hline $\begin{array}{l}\text { Host Country - } \\
\text { Licensing }\end{array}$ & 115 & 87 & $\begin{array}{l}\text { Revenue in USD } \\
\text { Millions }\end{array}$ \\
\hline & $\begin{array}{l}\text { Revenue in USD } \\
\text { Millions }\end{array}$ & $\begin{array}{l}\text { Revenue in USD } \\
\text { Millions }\end{array}$ \\
\hline
\end{tabular}

In addition to financially supporting the operations of the Olympics, the TOP Sponsors have joined the IOC in finding ways to actively share the mission in a variety of ways that go beyond the games themselves. How do the Sponsors and IOC do this? To begin, it may be useful to know that the Olympic Movement has a very broad mission. Specifically, as stated in the most recent version of the Olympic Charter its mission is as follows: "Under the supreme authority and leadership of the International Olympic Committee, the Olympic Movement encompasses organizations, athletes and other persons who agree to be guided by the Olympic Charter. The goal of the Olympic Movement is to contribute to building a peaceful and better world by educating youth through sport practiced in accordance with Olympism and its values." (Olympic Charter, 2020, p.15).

Given the breadth of the Olympic Movement's mission, the IOC has already identified five areas that they define as "beyond the Games" where it is possible for them to enhance the societal impact of the Olympics. These areas of enhanced societal impact include: fighting against doping, gender equality, legacy, refugees, and sustainability (Olympic Partner Programme, 2021). In each of these areas specific initiatives are already underway to make a positive difference in world (Olympic Partner Programme, 2021).

How do TOP Sponsors share in this important work? Many unique approaches have already been undertaken. Some recent, illustrative examples include the following initiatives. Coca-Cola's selection of a diverse group of Placard Bearers to lead out athlete delegations as a way of promoting diversity and inclusion at the Tokyo 2020 Opening Ceremony. Toyota's introduction of a wide range of innovative mobility solutions (e.g., large doors and electric ramps to ease passenger movement) into vehicles to help with the transport of athletes and officials at the Tokyo 2020 Olympic Games. General Electric's provision of cutting-edge healthcare to treat athletes during the Tokyo 2020 Olympic Games. In addition, Proctor \& Gamble $(P \& G)$ has started a program to recognize athletes for good acts (e.g., peer counseling for athletes experiencing stress at the Games). Once identified for their good work these athletes can then have P\&G donate a grant to a charity of the athlete's choosing (Olympic Partner Programme, 2021).

\section{DISCUSSION}

The above findings have theoretical and practical implications for anyone interested in learning more about how sustainability-focused strategies can help nonprofits to pursue their double bottom-line goals of money and mission (Kickul \& Lyons, 2020). To begin, from a sociological, neo-institutional theoretical perspective (David et al., 2019), it provides additional evidence that how a program is structured can be an 
important factor in the long-term success of an organizational development change effort. In this instance, how a structured program helped a global sports nonprofit to adapt to changes in its external environment through the creation of a shared value (Porter \& Kramer, 2011) interorganizational (Franke, 2017) social alliance (Berger, et al, 2004) with an evolving group of global private-sector partners over a period of many years.

In terms of general policy development and practice (Miragaia et al, 2017), the findings from this examination will also hopefully provide food-for-thought to nonprofit leaders on the potential value in using a new or enhancing an existing interorganizational strategy to the pursuit of their double bottom-line goals. More precisely, beyond the fact that the contributions of Sponsors in this program to the Olympics have significantly grown over time while the size of the membership has remained relatively small (Roland, 2004), what features in the design of the TOP Sponsors program seem to have contributed the most to its long-term success as a sustainability-focused strategy (McDonald et al, 2015)? Here, three features seem to stand our most boldly. First, as articulated in Austin's (2000) collaboration framework, this program was not designed to solicit philanthropic gifts. Instead, it was intended to be a step toward a deeper and broader partnership with a small number of global for-profit firms. Specifically, the IOC sought partners who would receive special Olympic marketing rights in return for the firm's support of both the Olympics' operations and mission. Second, in joining this program, a firm would be making a commitment to support the Olympics for a full, four-year cycle and not just a single event or activities. Third, that commitment would be to support both the operations and mission of the Olympic Movement. So, by joining the TOP program the Sponsors would be making a significant, multi-year commitment to the Olympics fiscal and social sustainability, double bottom-line goals.

Looking deeper into some of the more specific details in the design of this program there are additional ideas for practitioners to consider. First, as noted earlier, this program was not intended to be based on oneon-one relationships between the IOC and individual Sponsors. Rather it was to build to enlist a small cadre of Sponsors who would unite to collectively support the Olympics for a four-year cycle. As a result, to more fully appreciate how this type of program worked in practice, it became important to also investigate the composition and structure of the Sponsor membership over time. In doing so, concepts from interorganizational network analysis (Carroll \& Sapinski, 2011) as well as basic network analysis (Marin \& Wellman, 2011). were used to learn more about the evolving composition and structure of the network over time.

From the above analysis, some additional insights emerged about the long-term composition and structure of the TOP Sponsors network that could be of potential interest to practitioners. Specifically, in terms of "Spatiality" it was interesting to note that while one of the important aims of this program was to support the Olympics throughout the world, in the first round of funding the Sponsors came overwhelmingly from companies headquartered in the United States. By the ninth funding cycle there was more diversity around where the companies were headquartered, but half of the Sponsors were still headquartered in the United States. Second, as to "Temporality" it was notable that in every funding cycle, to date, there have always been at least one departing and/or one new member joining the program. Third, in terms of the nominal length of commitment by Sponsors to the program, it was striking to see that there was a wide range on this dimension, from three firms that had sponsored all nine funding cycles to five firms that had only supported one cycle and then left the program.

Finally, since the ultimate purpose for developing and implementing a sustainability-based strategy is to increase a nonprofit's societal impact (DeRycke \& DeBosscher, 2019), from a practical standpoint it is appropriate to end this discussion by asking in what ways did this interorganizational approach help to reach this goal. As discussed earlier, it was evident that this program did so in two ways. First, by providing significant funding for the core Olympic operations, it directly increased the size and number of ways that individuals could participate in this mega-sporting event. Second, by having Sponsors expand on the Olympics" "beyond the Games" efforts through the creation of their own unique, beyond the Games, initiatives, certainly aided in sharing the message about the mission of the Olympic Movement. 


\section{SUMMARY AND CONCLUSION}

This paper describes and analyzes how one structured, interorganizational program, launched by the IOC in 1985, has become another important part of the Olympic Movement's overall approach to enhancing its positive impact on society. At the same time, it illustrates how it is possible to successfully pursue a nonprofit's double bottom-line, operational and mission goals, by carefully designing and implementing a social alliance with an evolving group of global for-profit firms.

While this study can provide other nonprofits with some ideas on why and how an interorganizational, sustainability-focused strategy could potentially provide them with another complementary way to pursue their own double bottom-line goals, this examination does have limitations in terms of its breadth, depth, and focus that need to be mentioned. Those limitations, however, also suggest ideas for future work in this area. For example, to add more breath to this examination, it would be useful to know more about the experiences that national and regional nonprofits may have had in creating their own interorganizational social alliances. Second, to add more depth to this analysis, it would be interesting to learn more about the deeper reasons why some of the TOP Sponsors have continued to support the Olympic Movement for decades while other Sponsors left after only participating in one funding cycle. Third, in terms of focus, this study has only looked at the ways in which this interorganizational approach has positively impacted society. Moving forward it could be equally informative to learn of any ways in which this strategy has also led to negative impacts on society.

In conclusion, hopefully, this paper has stimulated interest among other researchers and practitioners to learn more about the ways in which sustainability-focused strategies can help nonprofits in their efforts to enhance their positive impact on society. The need is great. The knowledge would be welcomed.

\section{ACKNOWLEDGEMENT}

The author wishes to express thanks to the Dean's Office of the Barney School of Business at the University of Hartford for the financial support it provided to help develop this paper.

\section{REFERENCES}

Austin, J.E. (2000). Strategic collaboration between nonprofits and business. Nonprofit and Voluntary Sector Quarterly, 29(1), 69-97. doi: 10.1177/0899764000291S004

Berger, I.E., Cunningham, P.H., \& Drumwright, M.E. (2004). Social alliances: Company/Nonprofit collaboration. California Management Review, 47(1), 58-90.

Berry, L.L., Reibstein, D.J., Wijen, F., Van Wassenhove, L., Voss, C., Gustafsson, A., . . Bolton, R. (2021, February 8). Encouraging Business Scholars to address Social Impact. AACSB International Business and Research in Real Time.

Carroll, W.K., \& Sapinski, J.P. (2011). Corporate elites and intercorporate networks. In J. Scott \& P.J. Carrington (Eds.), The SAGE handbook of social network analysis (pp. 180-195). Thousand Oaks, CA.: SAGE Publications.

Dacin, M.T., Goodstein, J., \& Scott, W.R. (2002). Institutional theory and institutional change: Introduction to the special research forum. Academy of Management Journal, 45, 43-46.

David, R.J., Tolbert, P.S., \& Boghossian, J. (2019). Institutional theory in organization studies. Oxford Research Encyclopedia of Business and Management. https://doi.org/10.1093/acrefore/9780190224851.013.158

DeRycke, J., \& DeBosscher, V. (2019). Mapping the potential societal impacts triggered by elite sport: A conceptual framework. International Journal of Sport Policy and Politics, 11(3), 485-502.

DiMaggio, P.J. (1988). Interest and agency in institutional theory. In L.G. Zucker (Ed.), Institutional patterns and organizations (pp. 3-22). Cambridge, MA: Ballinger.

DiMaggio, P.J., \& Powell, W.W. (1983). The iron cage revisited: Institutional isomorphism and collective rationality in organizational fields. American Sociological Review, 48, 147-160. 
Franke, U. (2017). Inter-organizational relations: Five theoretical approaches. Oxford Research Encyclopedia of International Studies, pp. 1-26. https://doi.org/10.1093/acrefore/9780190846626.013.99

Gratton, C., \& Taylor, P. (2000). Economics of sport and recreation. New York: Routledge.

Gratton, C., Dobson, N., \& Shibli, S. (2000). The economic importance of major sports events: A casestudy of six events. Managing Leisure, 5, 17-28.

Greenwood, R., Oliver, C., Lawrence, T., \& Meyer, R. (Eds.). (2017). The Sage handbook of organizational institutionalism (2nd ed.). London: SAGE.

Greenwood, R., Oliver, C., Sahlin, K., \& Suddaby, R. (Eds.). (2008). The Sage handbook of organizational institutionalism. London: SAGE.

International Olympic Committee. (n.d.). Olympic Congress - Paris - 1894. Retrieved from https://www.olympic.org/paris-1894-olympic-congress

IOC. (n.d.). Olympic Marketing Fact File 2020 Edition. Retrieved from https://stillmed.olympic.org/media/Document\%20Library/OlympicOrg/Documents/IOCMarketing-and-Broadcasting-General-Files/Olympic-Marketing-Fact-File.pdf

Kickul, J., \& Lyons, T.S. (2020). Understanding social entrepreneurship: The relentless pursuit of mission in an ever changing world (3rd Ed.). New York, NY: Routledge.

Marin, A., \& Wellman, B. (2011). Social network analysis: An introduction. In J. Scott \& P.J. Carrington (Eds.). The SAGE handbook of social network analysis (pp. 11-25). Thousand Oaks, CA.: SAGE Publications.

McDonald, R.E., Weerawardena, J., Madhaven, S., \& Sullivan Mort, G. (2015). From "virtuous" to "pragmatic" pursuit of social mission: A sustainability-based typology of nonprofit organizations and corresponding strategies. Management Research Review, 38(9), 970-991. https://doi.org/10.1108/MRR-11-2013-0262

Meyer, J.W., \& Rowan, B. (1977). Institutionalized organizations: Formal structure as myth and ceremony. American Journal of Sociology, 83, 340-363.

Miragaia, D.A.M., Ferreira, J., \& Ratten, V. (2017). Corporate social responsibility and social entrepreneurship: Drivers of sports sponsorship policy. International Journal of Sport Policy and Politics, 9(4), 613-623.

Müller, M. (2015). What makes an event a mega-event? Definitions and sizes. Leisure Studies, 34(6), 627-642.

Müller, M., \& Gaffney, C. (2018). Comparing the urban impacts of the FIFA World Cup and Olympic Games from 2010 to 2016. Journal of Sport and Social Issues, 42(4), 247-269.

Olympic Charter. (2020). In Force as from 17 July 2020. Retrieved from https://stillmed.olympic.org/ media/Document\%20Library/OlympicOrg/General/EN-Olympic-Charter.pdf

Olympic Partner Programme. (2021). Retrieved from https://olympics.com/ioc/partners

Porter, M.E., \& Kramer, M.R. (2011). Creating shared value. Harvard Business Review, 89(1/2), 62-77.

Roche, M. (2017). Mega-events and social change: Spectacle, legacy and public culture. Manchester, UK: Manchester University Press.

Roland, G. (2004). Understanding institutional change: Fast-moving and slow-moving institutions. Studies in Comparative International Development, 38(4), 109-131.

The Olympic Studies Centre. (2017). TOP Marketing Program Historic Overview 19.06.2017. Retrieved from file:///C:/Users/18602/Downloads/2017-06-17\%20-\%20PUBLIC\%20\%20TOP\%20Marketing\%20Program\%20Historic\%20Overview\%20(TOP\%20I\%20to\%20TOP\% 20IX)\%20-\%20eng\%20(3).pdf

Tolbert, P.S., \& Zucker, L.G. (1983). Institutional sources of change in the formal structure of organizations: The diffusion of civil service reform, 1880-1935. Administrative Science Quarterly, 28, 22-39.

Zorn, D.M. (2004). Here a chief, there a chief: The rise of the CFO in the American firm. American Sociological Review, 69, 345-364.

Zucker, L.G. (1977). The role of institutionalization in cultural persistence. American Sociological Review, 42, 726-743. 